\title{
SINDROMA STOKES-ADAMS: SINKOP KARDIAK YANG MIRIP BANGKITAN
}

\author{
Putu Lohita Rahmawati ${ }^{1}$, I Wayan Widyantara ${ }^{1}$, I Made Putra Swi Antara ${ }^{2}$ \\ ${ }^{1}$ Departemen Neurologi, FK Universitas Udayana/RSUP Sanglah, Denpasar, Bali, Indonesia \\ ${ }^{2}$ Departemen IImu Jantung dan Pembuluh Darah, FK Universitas Udayana/RSUP Sanglah, Denpasar, Bali, \\ Indonesia
}

Diterima 1 Agustus 2019

Disetujui 31 Agustus 2019

Publikasi 1 September 2019

Korespondensi: putulohita@gmail.com
Cara merujuk artikel ini: Lohita (et al). 2019. Sindroma Stokes-Adams: Sinkop Kardiak Yang Mirip Bangkitan. Callosum Neurology Journal 2(3): 128-133. DOI: https://doi.org/10.29342/cnj.v2i3.90

\section{ABSTRAK}

Latar Belakang: Kesalahan dalam mengidentifikasi suatu sinkop sebagai bangkitan epileptik merupakan hal yang sering terjadi. Masalah kardiovaskular harus dipertimbangkan karena keterlambatan identifikasi meningkatkan mortalitas.

Kasus: Pasien dengan bangkitan umum motorik tonik klonik lebih dari 20 kali dalam waktu 18 jam dengan durasi 3-5 menit. Pemeriksaan fisik menunjukkan bradikardia, kardiomegali dengan bising sistolik mitral dan tidak didapatkan defisit neurologis lainnya. Gambaran EKG menunjukkan AV blok derajat 3 dengan gambaran ekokardiografi dilatasi ventrikel kiri dengan regurgitasi moderat katup mitral. Dilakukan pemasangan alat pacu jantung sementara dan setelahnya pasien tidak mengalami bangkitan.
Diskusi: Aktivitas tonik klonik seperti bangkitan epileptik dapat terjadi pada pasien dengan sinkop akibat AV blok. Penurunan kesadaran mendadak sesaat disertai aktivitas seperti bangkitan akibat aritmia yang menyebabkan penurunan perfusi serebral disebut sindroma Stokes-Adams. Aktivitas tonik klonik pada keadaan ini tidak responsif terhadap antikonvulsan.

Simpulan: Laporan kasus ini penting untuk membedakan sinkop kardiak dengan bangkitan epileptik. Kesalahan identifikasi menyebabkan keterlambatan penanganan dan meningkatkan mortalitas.

Kata Kunci: Sindroma Stokes-Adams, sinkop kardiak, AV blok 


\section{Latar Belakang}

Epilepsi merupakan permasalahan neurologi dengan prevalensi yang tinggi yaitu 7.06 per 1000 orang di seluruh dunia. Prevalensi ini lebih tinggi pada negara miskin dan berkembang, yaitu lebih dari 10 per 1000 orang.1 Masalah kesehatan ini sangat berhubungan dengan stigma serta berbagai permasalahan psikososial bagi para penderitanya. Oleh karena itu, diagnosis epilepsi harus ditegakkan dengan teliti.2

Adanya bangkitan merupakan salah satu penyebab terbanyak seseorang dibawa ke unit gawat darurat.3 Namun, tidak semua aktivitas yang mirip bangkitan merupakan bangkitan epileptik. Beberapa kelainan sistem kardiovaskular dilaporkan menyebabkan penderita mengalami penurunan kesadaran mendadak disertai dengan gerakan abnormal yang mirip dengan bangkitan epileptik.4 Keadaan ini sangat mirip dengan bangkitan epileptik sehingga menyebabkan kesalahan dalam menegakkan diagnosis epilepsi.5 Kesalahan dalam menegakkan diagnosis epilepsi tidak hanya akan membawa konsekuensi klinis bagi pasien namun juga beban sosial ekonomi.5,6 Sementara itu, kegagalan dalam mengidentifikasi gangguan kardiovaskular sebagai penyebab dasar pada keadaan tersebut berpotensi membawa konsekuensi yang fatal bagi pasien oleh karena meningkatkan resiko mortalitas.6 Pada laporan kasus ini, kami melaporkan pasien dengan sinkop kardiak akibat blok total atrioventrikular (AV blok) dengan gambaran klinis mirip bangkitan.

\section{Ilustrasi Kasus}

Seorang pasien laki-laki, suku Bali, 26 tahun, yang bekerja sebagai buruh bangunan, dirujuk ke IGD kardiologi RSUP Sanglah dari RSUD karena didiagnosa mengalami blok atrioventrikuler (AV block). Pasien kemudian dikonsultasikan ke neurologi karena dilaporkan mengalami kejang berulang-ulang.

Dari hasil anamnesis terhadap pasien dan keluarga, didapatkan informasi bahwa dalam rentang waktu 18 jam sebelum di bawa ke RSUP, pasien mengalami serangan seperti kejang lebih dari 20 kali. Sebelum kejang terjadi, dikatakan kesadaran pasien baik. Kemudian tiba-tiba pasien tidak sadar diikuti dengan kedua tangan dan kedua kaki kelojotan. Selama kejang pasien tidak sadar, dan setelah kejang berhenti pasien langsung sadar baik. Setiap kejang berlangsung selama kurang lebih 3-5 menit.
Pasien tidak merasakan pusing berputar atau kepala terasa ringan, dada berdebar maupun keluar keringat dingin sebelum ia kehilangan kesadaran. Tidak ada tanda-tanda lidah tergigit saat pasien tersebut mengalami kejang. Kesadaran pasien kembali secara cepat tanpa ada periode bingung setelah penurunan kesadaran dan pasien mengatakan bahwa ia bisa mengingat semua aktivitasnya sesaat sebelum kehilangan kesadaran. Oleh karena pasien datang ke RSUD dengan keluhan kejang, pasien ditangani sebagai pasien kejang dan diberikan obat anti konvulsan diazepam $10 \mathrm{mg}$ bolus intravena setiap kali kejang terjadi. Pasien mendapatkan 4 kali suntikan obat tersebut namun kejang terus muncul berulang kali. Setelah dilakukan pemeriksaan EKG, diketahui bahwa pasien menderita gangguan irama jantung sehingga kemudian di rujuk ke RSUP Sanglah dengan diagnosis sementara total AV block dan observasi konvulsi.

Kejang seperti ini dialami oleh pasien pertama kali pada 2 bulan yang lalu. Dalam kurun waktu tersebut, keadaan ini berulang sebanyak 5 kali. Serangan penurunan kesadaran dengan kejang ini dikatakan terjadi secara acak. Terkadang terjadi saat pasien sedang beraktivitas, sedang duduk beristirahat maupun saat pasien baru bangun dari tidur. Pasien sempat berobat ke Puskesmas dan dikatakan menderita darah tinggi serta diberi obat anti hipertensi yang pasien tidak bisa mengingat nama obatnya. Pasien tidak pernah kontrol lagi ataupun melanjutkan minum obat setelah obat yang didapat dari puskesmas habis.

Saat dilakukan pemeriksaan secara umum tampak pasien lemah namun sadar baik. Tekanan darah pasien 136/33 mmHg dengan nadi 33 kali permenit dengan irama yang ireguler. Dari pemeriksaan dada didapatkan kesan kardiomegali dengan bising sistolik mitral. Tidak didapatkan defisit neurologis selain adanya riwayat bangkitan umum motorik tonik klonik.

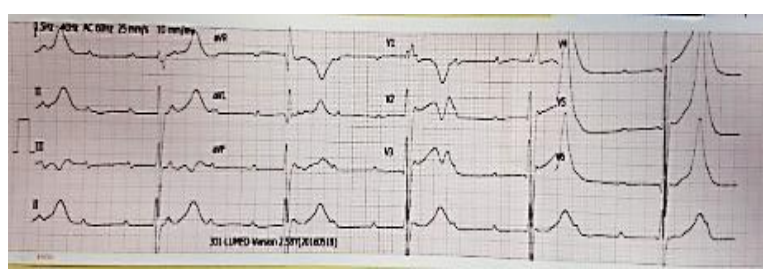

Gambar 1. Gambaran EKG menunjukkan adanya AV block derajat 3

Pada pemeriksaan darah rutin didapatkan leukositosis $(17,67 \times 103 / \mu \mathrm{L})$. Pemeriksaan kimia 
darah, analisis gas darah dan elektrolit dalam batas normal. Hasil elektrokardiografi menunjukkan adanya AV block derajat 3 (Gambar 1). Gambaran $\mathrm{X}$-foto thorax menunjukkan adanya kardiomegali memperkuat temuan yang didapatkan pada pemeriksaan fisik (Gambar 2). Pemeriksaan ekokardiografi menunjukkan bahwa terdapat dilatasi ventrikel kiri yang eksentrik dengan fraksi ejeksi $74 \%$ serta terdapat gangguan katup berupa regurgitasi katup aorta derajat berat, regurgitasi mitral sedang dan regurgitasi pulmonal serta trikuspidalis ringan.

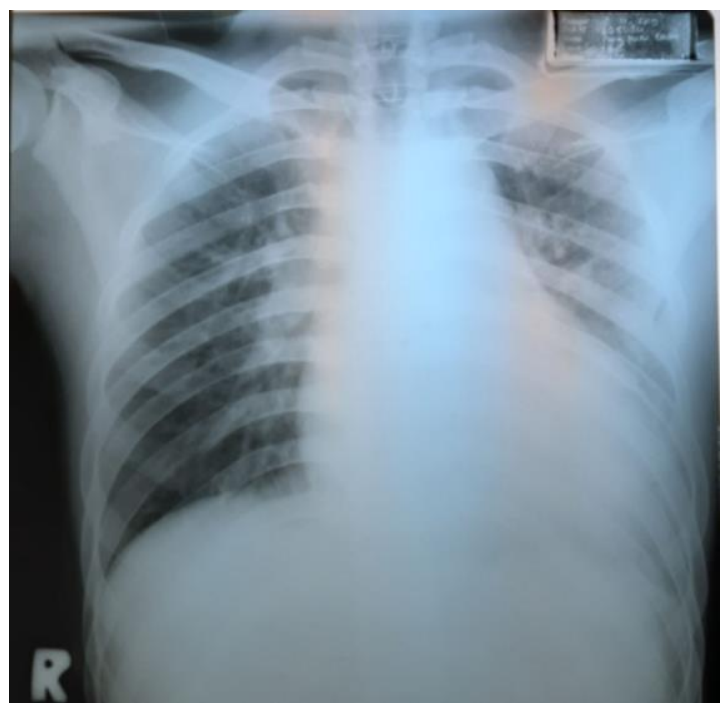

Gambar 2. X-foto thoraks menunjukkan kardiomegali

Pasien diberikan terapi dengan sulfas atropin sebelum kemudian mejalani pemasangan alat pacu jantung sementara dan mendapatkan perawatan di ruang rawat ICCU. Setelah pemasangan alat pacu jantung sementara keadaan umum pasien membaik dengan tekanan darah 130/60 mmHg dan nadi 72 kali per menit. Setelah hemodinamik pasien stabil, pasien tidak mengalami lagi serangan penurunan kesadaran dengan kejang. Kemudian dilakukan elektroensefalografi (EEG) dalam rangka mengevaluasi kemungkinan adanya potensial epileptogenik pada pasien. Hasil pemeriksaan EEG didapatkan EEG dengan klasifikasi normal (bangun dan tidur stadium II). Pasien kemudian menjalani pemasangan alat pacu jantung permanen 3 bulan kemudian.

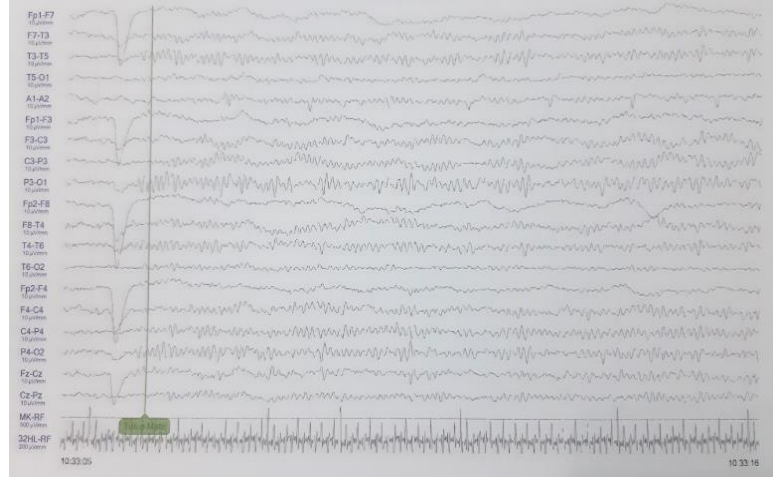

Gambar 3. Hasil pemeriksaan EEG normal

\section{Diskusi}

Pada kasus ini, episode serangan dengan penurunan kesadaran disertai dengan gerakan tonik klonik sangat mirip dengan bangkitan epileptik. Pada pasien ini, episode tersebut didasari oleh adanya gangguan irama jantung. Akibatnya, terjadi hipoperfusi serebral yang bersifat sementara yang menyebabkan terjadinya hipoksia global pada serebral yang bermanifestasi sebagai sebuah sinkop. Sinkop didefinisikan sebagai penurunan kesadaran yang bersifat sementara oleh karena hipoperfusi serebral, ditandai dengan onset yang cepat, durasi singkat dan kembalinya kesadaran secara spontan. ${ }^{7}$

Sinkop yang disertai dengan gerakan involunter mirip suatu bangkitan seperti yang dialami pasien ini pertama kali dideskripsikan oleh Robert Adams dan William Stokes sehingga dinamakan Sindroma Stokes-Adams. Sindroma ini merupakan suatu sinkop kardiak yang didefinisikan sebagai penurunan kesadaran yang terjadi mendadak dan sementara dengan gambaran kejang oleh karena gangguan perfusi serebral yang disebabkan oleh aritmia seperti blok jantung total, fibrilasi ventrikel dan takikardia ventrikular dengan denyut lambat. ${ }^{8}$ Berbagai studi telah melaporkan banyak pasien dengan sinkop kardiak ini telah salah didiagnosis sebagai epilepsi refrakter dan mendapatkan terapi OAE dengan segala resiko efek sampingnya.,9 Sebuah studi terhadap pasien yang mendapatkan terapi epilepsi di klinik spesialis melaporkan tingkat kesalahan diagnosis sebesar 26\%.10 Studi lain dengan pendekatan komunitas melaporkan bahwa kesalahan diagnosis terjadi sebesar 23\%. ${ }^{11}$ Pada kedua studi tersebut, didapatkan bahwa sinkop kardiovaskular merupakan keadaan yang paling 
sering secara salah didiagnosis sebagai epilepsi. ${ }^{10,11} \mathrm{Di}$ Indonesia sendiri belum ada studi mengenai hal ini.

Gambaran klinis sindroma ini sangat mirip dengan bangkitan epileptik. Pasien datang ke unit gawat darurat dengan keluhan utama kejang sebagai suatu manifestasi klinis yang mudah diidentifikasi dan merupakan kejadian yang menakutkan bagi orang awam. Bagi klinisi di pelayanan gawat darurat, sangat diperlukan pemahaman untuk dapat membedakan antara sinkop dan kejang sehingga dapat melakukan penanganan tepat dalam proses penegakan diagnosis dan selanjutnya menentukan terapi yang sesuai.

Langkah pertama yang harus dilakukan dalam menghadapi pasien dengan kejang pertama kali adalah memastikan terlebih dahulu apakah episode serangan yang diinterpretasikan sebagai kejang oleh pasien dan keluarga tersebut benarbenar merupakan suatu kejang atau bangkitan. Laporan mengenai adanya gerakan involunter tonik klonik selama pasien mengalami penurunan kesadaran mengindikasikan suatu bangkitan. Namun, anamnesis yang seksama harus dilakukan pada saksi mata untuk mendapatkan informasi yang lengkap mengenai episode serangan tersebut. Apabila kesadaran pasien baik dan kooperatif, perlu ditanyakan beberapa informasi subjektif yang dapat membantu membedakan bangkitan dengan beberapa kondisi klinis mirip bangkitan. ${ }^{3}$ Perasaan kepala ringan, mual, dada berdebardebar atau keluar keringat dingin sebelum serangan mengarahkan pada sinkop. Penurunan kesadaran sementara dengan bangkitan yang diikuti dengan kembalinya kesadaran secara spontan tanpa adanya fase bingung atau konfusi post iktal lebih cenderung ke arah sinkop daripada kejang. ${ }^{12}$ Penurunan kesadaran dengan bangkitan tanpa provokasi yang terjadi kardiovaskular sehingga dapat menyingkirkan kemungkinan sinkop sebelum sempat mempertimbangkan pemeriksaan imaging untuk mencari proses patologis di otak. ${ }^{9}$

Pemeriksaan EKG 12 lead merupakan pemeriksaan penunjang awal yang esensial pada pasien dengan bangkitan dan dicurigai sinkop kardiak. ${ }^{7}$ Gangguan irama yang teridentifikasi pada pemeriksaan EKG memperkuat patologi kardiak sebagai salah satu faktor pencetus berulang-ulang dimana setiap episode berlangsung dengan singkat mengindikasikan suatu sinkop kardiak. ${ }^{4}$ Pada beberapa kasus klasik dari sindroma Stokes-Adams, penurunan kesadaran berlangsung sangat singkat sehingga pasien langsung melanjutkan aktivitasnya tanpa menyadari adanya episode penurunan kesadaran tersebut. ${ }^{13}$

Informasi dari proses anamnesis ini digunakan untuk menghitung skor Sheldon yang pada praktik klinis secara luas dipergunakan sebagai kriteria diagnostik untuk membedakan bangkitan dengan sinkop.12 Skor lebih dari sama dengan 1 mengarahkan diagnosis ke bangkitan. Namun, untuk sinkop kardiogenik, penggunaan skor ini cenderung menyebabkan adanya penilaian yang false positive. Seperti pada pasien di kasus ini, jika dihitung skor Sheldonnya pasien adalah 1, mendukung ke arah suatu bangkitan. Pada sinkop kardiak, penurunan keasadaran yang terjadi sangat mendadak tanpa didahului oleh gejala prodormal oleh karena hipoperfusi dan anoxia serebral yang terjadi secara tiba-tiba. Gejala seperti kepala ringan atau dizziness, diaporesis, nausea dan penurunan kesadaran berhubungan dengan posisi berdiri yang lama lebih merupakan karakteristik dari sinkop vasovagal. ${ }^{9}$

Kecurigaan ke arah sinkop juga diperkuat apabila pasien tidak memiliki riwayat kejang sebelumnya atau bangkitan seperti ini baru pertama kali dialami pada pasien dewasa atau usia tua. ${ }^{6,8,9}$ Secara epidemiologi, bangkitan epileptik dengan onset usia dewasa pada umumnya merupakan epilepsi simtomatik dengan dasar patologi otak yang jelas seperti stroke, trauma atau tumor. Pada seting pelayanan gawat darurat, data ini harus menuntun klinisi untuk melakukan evaluasi secara menyeluruh terhadap fungsi

terjadinya gangguan kesadaran sementara yang disertai gerakan seperti bangkitan pada pasien. ${ }^{8}$ AV blok derajat 3 atau yang sering disebut sebagai total AV blok merupakan penyebab utama dari sindroma Stokes-Adams seperti yang terjadi pada kasus ini. ${ }^{13}$ Pada keadaan ini, gangguan transmisi impuls atrioventrikular dapat menyebabkan periode asistol sebelum pacemaker ventrikular mulai bekerja sebagai mekanisme kompensasi. Periode asistol 
menyebabkan penurunan perfusi serebral dan terjadi sinkop. ${ }^{4}$

Pemeriksaan EEG pasien sinkop kardiak menunjukkan karakteristik anoksia serebral didapatkan saat otak mengalami hipoperfusi akibat aritmia tersebut. Gangguan irama yang menimbulkan periode asistol menyebabkan aktivitas EEG hilang secara total pada periode tersebut. Koreksi terhadap keadaan ini sesegera mungkin sebelum menjadi ireversibel akan mengembalikan gambaran EEG yang normal. ${ }^{5}$ Manajemen yang adekuat di pelayanan gawat darurat akan mengarahkan klinisi untuk dapat mengidentifikasi adanya gangguan jantung pada pasien dengan gejala klinis mirip bangkitan. Sehingga, penggunaan OAE secara salah dapat dihindari dan penatalaksanaan yang tepat dapat diberikan untuk mencegah mortalitas pada pasien. Pemberian OAE pada pasien dengan kardiak sinkop dapat memperburuk keadaan pasien. Pasien dengan sinkop kardiak yang secara salah diidentifikasi sebagai bangkitan epileptik akan mendapatkan diazepam sebagai manajemen awal sesuai pedoman penatalaksanaan. Diazepam sebagai suatu agen antikonvulsi memiliki efek dromotropik negatif yang dapat memperburuk gangguan konduksi nodus AV. ${ }^{14}$

Penanganan awal pada pasien dengan sinkop kardiak adalah dengan pemberian agen vagalitik sulfas atropin. Regimen ini diberikan untuk sementara sambil menunggu terapi definitif

\section{Daftar Rujukan}

1. Fiest, K. M., Sauro, K.M., Wiebe, S., Patten, S.B., Kwon, C.S., Dykeman, J., Pringsheim, T., Lorenzetti, D.L., and Jette, $\mathrm{N}$. Prevalence and incidence of Epilepsy: A systematic review and meta-analysis of international studies. Neurology. 2017;88(3):296-303.

2. Sinardja, A.M.G. dan Hawari, I. Aspek Psikososial Epilepsi. In Kusumastuti, K., Gunadharma, S. Dan Kustiowati, E., eds. Pedoman Tatalaksana Epilepsi. 5th ed. Surabaya:Airlangga University Press;2014: 77-80.

3. Bank, A. B., dan Bazil, C.W. Emergency Management of Epilepsy and Seizure. Seminars in Neurology. 2019;39(1):73-81.

4. You, C.F., Chong, C.F., Wang, T.L., Hung, T. Y., and Chen, C.C. Unrecognized berupa munculnya gelombang lambat dengan ritme theta atau delta. Pada kasus sinkop kardiak dengan episode serangan yang bersifat sementara, gambaran EEG abnormal ini berupa pemasangan alat pacu jantung. Satu serangan sinkop Stokes-Adams pada pasien dengan AV block derajat 3 merupakan indikasi yang kuat untuk pemasangan alat pacu jantung. ${ }^{13}$

\section{Simpulan}

Membedakan antara bangkitan epileptik dengan sinkop kardiak bukan merupakan pekerjaan yang mudah terutama pada seting pelayanan gawat darurat. Adanya informasi mengenai gerakan involunter seperti bangkitan seringkali membawa klinisi pada prosedur penegakan diagnosis yang mengarah kepada bangkitan epileptik. Perhatian yang lebih kepada profil pasien serta anamnesis yang detil terkait serangan yang bisa membantu menghindari keasalahan dalam manajemen pasien yang berujung pada kesalahan diagnosis dan terapi serta meningkatkan mortalitas. Adanya permasalahan kardiovaskular harus tetap menjadi bahan pertimbangan dalam kasus seperti ini. Pemeriksaan EKG 12 lead harus menjadi bagian integral dan esensial dari manajemen awal pasien dewasa yang datang dengan onset pertama penurunan kesadaran mendadak dan sementara disertai bangkitan.

paroxysmal ventricular standstill masquerading as epilepsy: a StokesAdams attack. Epileptic Disord. 2007;9(2):179-81.

5. Zaidi, A., Clough, P., Cooper, P., Scheepers, B., Fitzpatrick, A.P. Misdiagnosis of Epilepsy: Many Seizure-Like Attacks Have a Cardiovascular Cause. Journal of the American College of Cardiology. 2000;36(1):181-184.

6. Gambardella, A., Curcio, A., Labate, A., Mumoli, L., Indolfi, C., and Quattrone, A. Blocking out the real diagnosis. Lancet. 2011;377(9766):690.

7. Task Force for the diagnosis and management of syncope of the European Society of Cardiology. 2018 ESC Guidelines for the diagnosis and management of 
syncope. Europeam Heart Journal/ 2018;39:1883-1948.

8. Seth, R., Mishra, D.G., and Chhabra, S. Misdiagnosing Epilepsy: A Case Report on Stokes-Adams Syndrome. Clinical Case Reports International-Emergency Medicine. 2018;2:1-4.

9. Labate. A., Mumoli, L., Curcio, A., Tripepi, G., D’arrigo, G., Ferlazzo, E., Aguglia, U., Indolfi, C., Quattrone, A., and Gambardella, A. Vallue of clinical features to differentiate refractory epilepsy from mimics: a prospective longitudinal cohort study. European Journal of Neurology. 2018;0:1-7.

10. Smith, D; Defalla, B.A., and Chadwick, D.W. The misdiagnosis of epilepsy and the management of refractory epilepsy in a sepcialist clinic. QJ Med. 1999:92:15-23.

11. Scheepers, B., Clough, P., and Pickels, C. The misdiagnosis of epilepsy: findings of a population study. Seizure. 1998:5:403-6.

12. Sheldon, R.. Rose, S., Ritchie, D., Connoly, S.J., Koshman, M., Lee, M.A., Frenneaux, M., Fisher, M., and Murphy, W. Historical Criteria That Distingusih Syncope From Seizure. Journal of the American College of Cardiology. 2002:40(1): 142-148.

13. O'Rourke, R.A. The Stokes-Adams Syndrome. The Western Journal of Medicine. 1972;17(1):96-99.

14. Anand, K., and Kumar, M. Benzodiazepine overdose associated atrioventricular block. Anesthesia: Essay and Reasearches. 2013;7(3): 419-420. 